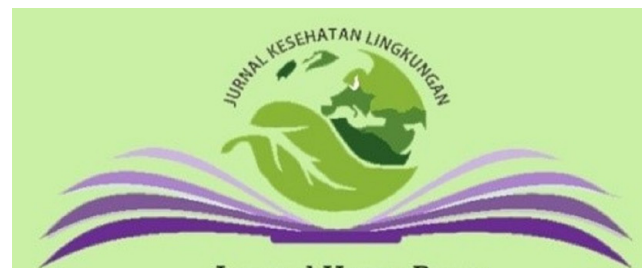

Journal Home Page:

https://e-journal.unair.ac.id/JKL

\section{Jurnal Kesehatan Lingkungan}

Vol. 13 No. 4

DOI: $10.20473 /$ jkl.v13i4.2021.199-203

ISSN: 1829 - 7285

E-ISSN: 2040 - 881X

\title{
HOUSEHOLD SANITATION AS A DIARRHEA DRIVING FACTOR OF UNDER-FIVE CHILDREN IN BOJONEGORO REGENCY
}

\section{Taufik Imadudin ${ }^{1 *}$, Zida Husnina ${ }^{1}$, Retno Adriyani ${ }^{1}$}

${ }^{1}$ Department of Environmental Health, Faculty of Public Health, Universitas Airlangga, Surabaya 60115, Indonesia.

\section{Corresponding Author:}

*) taufik.imadudin-2017@fkm.unair.ac.id

\section{Article Info}

$\begin{array}{ll}\text { Submitted } & : \text { 20 June 2021 } \\ \text { In reviewed } & : \text { 22 June 2021 } \\ \text { Accepted } & : \text { 5 July 2021 } \\ \text { Available Online } & : \text { :31 October 2021 }\end{array}$

Keywords : Under-five children, Diarrhea, Household sanitation

Published by Fakultas Kesehatan Masyarakat Universitas Airlangga

\begin{abstract}
Introduction: Diarrhea incidence in children under five increases by $11 \%$ in Indonesia during 2013-2018 that could be driven by poor environmental sanitation. This study examined the relationship between environmental sanitation with diarrhea incidence in children under five. Methods: This study was an observational study with a cross-sectional design and used a total sampling technique of 81 underfive children. Primary data were collected by conducting interviews with parents using a structured questionnaire guideline and observation, including the source of drinking water, availability of healthy latrine, floor condition, and lighting. A Chi-square test $(\alpha=0.05)$ was conducted to analyse the relationship between variables. Results and Discussion: There was a significant correlation between household sanitation and diarrhea incidence in under-five children $(p=0.040$; $P R=1.202$ [95\% CI $0.987-1.463]$ ). Conclusion: Poor household sanitation can be a driving factor in diarrhea incidence in under-five children, where households categorised as good sanitation have 1.2 times lower risk than poor sanitation.
\end{abstract}

\section{INTRODUCTION}

WHO has been stated that sanitation is one of the important parameters in determining the quality of public health status (1). Environmental sanitation can be defined as an effort to fulfil basic sanitation needs, including access to excreta disposal, garbage disposal sites, wastewater sewer, and clean water (2). The house is the closest environment in carrying out people's daily activities, so sanitation must be considered. Based on the Ministerial Degree of Minstry of Health of Republic Indonesia No 829 Year 1999 about Housing Health Requirements, there are 10 conditions for healthy houses that need to be considered, namely building materials, lighting, air quality, ventilation, spatial planning, diseasetransmitting animals (vectors and rodents), clean water, residential density, food storage facilities, and waste management (3). The fulfillment of these requirements is to prevent the occupants from being susceptible to disease.

Diarrhea is an abnormal condition where the feces is more liquid and more frequent defecation than usual (4). Diarrhea is one infectious disease that often attacks under-five children even causes death (5). The condition of under-five children who are still in their infancy causes them to be susceptible to this disease. The prevalence of patients with infectious diseases such as ARI (Acute Respiratory Infection) and diarrhea in children under five in Indonesia is still quite high. Data and Information Center of the Indonesian Ministry of Health showed that diarrhea is the third-worst infectious disease after ARI and unknown fever with the prevalence among children under five 33,100 cases per 100,000 population in 2013 (6). According to the Indonesia Basic Health Research, the incidence of diarrhea in children under five was increasing in 2018 at 11\% (7). East Java Province has the second-highest diarrhea prevalence, which is estimated at 479,355 cases (8).

As an infectious disease of under-five children, diarrhea is influenced by various factors such as hygiene, sanitation, environmental conditions, parenting patterns, and others. According to a similar study in Sugi Waras, Public Health Centre in 2019, household sanitation that includes physical water quality, latrine ownership, and floor type can affect the emergence of diarrhea in underfive children (9). In addition, diarrhea morbidity can also have a worse impact on the nutritional status of the under-five children themselves, which the proportion of height and weight to age and cause children to suffer from malnutrition and stunting (10). 
According to the Health Profile of Bojonegoro Regency in 2019, the percentage of diarrhea cases in Bojonegoro Regency, 92\% of diarrhea cases in underfive children with the case are finding in Purwosari Subdistrict as many as 310 under-five children (100\%) (11). This study must be conducted to see the correlation between environmental sanitation factors and diarrhea incidence in under-five children.

\section{METHODS}

This study was quantitative observational using primary data with a cross-sectional design approach. The sample was 81 under-five children aged 0-59 months obtained through the total sampling technique. Data were obtained through interviews with parents of under-five children using a questionnaire. This study was conducted in January 2020 in Kuniran Village, Purwosari Sub-district, Bojonegoro Regency, East Java.

The independent variable in this study was household environmental sanitation, and the dependent variable was diarrhea cases in under-five children. Diarrhea was defined as a condition in which the underfive children had abnormal defecation (more frequent and more fluid) during the past two weeks before this study. Environmental sanitation requirements refer to the Ministry of Health Decree year of 2012, which include sources of drinking water with scoring weight 4 (refill $=1$, faucet water $=0$ ), availability of healthy latrines with scoring weight 3 (available $=1$, not available $=0$ ), floor conditions with scoring weight 2 (permanent $=1$, impermanent $=0$ ), and lighting with scoring weight 1 (adequate $=1$, deficient $=0$ ). The four indicators were then regrouped into two categories, good and poor household sanitation. The cut-off point used to determine which household category by the following calculation:

$$
\begin{aligned}
& \text { Cut-off Point }=\frac{(\text { Max Score }- \text { Min Score })}{2} \\
& \text { Cut-off Point }=\frac{(10-0)}{2}=5
\end{aligned}
$$

Household sanitation was considered a good category if the total score ranged $>5$ and poor category if the total score ranged $\leq 5$. The correlation analysis between diarrhea and household environmental sanitation using the Chi-Square test. This study has received ethical approval from the Health Research Ethics Commission of the Faculty of Nursing, University Airlangga No. 1769-KEPK.

\section{RESULTS}

The distribution of diarrhea occurrences in underfive children, gender, and household environmental sanitation showed in Table 1 and Table 2. As many as $12.3 \%$ of under-five children suffered diarrhea. Residents' drinking water sources more dominant from refill water than faucets were separated into local water processing companies and well water. The availability of latrines covers $2 / 3$ of all research respondents. Likewise, the lighting indicator shows more houses with sufficient lighting. Meanwhile, on the indicators of floor conditions, more than half of the respondent's houses show nonpermanent floors.

Table 1. Distribution of Under-Five Children Morbidity Frequency in Kuniran Village, Purwosari Sub-District, Bojonegoro Regency, East Java, January 2020

\begin{tabular}{cccc}
\hline \multicolumn{2}{c}{ Variable } & Frequency & Percentage (\%) \\
\hline Diarrhea & Yes & 10 & 12.3 \\
& No & 71 & 87.7 \\
\hline & Total & $\mathbf{8 1}$ & $\mathbf{1 0 0 . 0}$ \\
\hline
\end{tabular}

Table 2. Gender Frequency Distribution of Under-Five Children and Environmental Sanitation in Kuniran Village, Purwosari Sub-District, Bojonegoro Regency, East Java, January 2020

\begin{tabular}{lcc}
\hline \multicolumn{1}{c}{ Variable } & Frequency & Percentage (\%) \\
\hline Gender & & \\
Male & 44 & 54.3 \\
Female & 37 & 47.7 \\
$\quad$ Total & $\mathbf{8 1}$ & $\mathbf{1 0 0 . 0}$ \\
\hline Drink Water Source & & \\
$\quad$ Refill & 45 & 55.6 \\
Faucet & 36 & 44.4 \\
$\quad$ Total & $\mathbf{8 1}$ & $\mathbf{1 0 0 . 0}$ \\
\hline Healthy Latrine & & \\
Available & 55 & 67.9 \\
Not Available & 26 & 32.1 \\
Total & $\mathbf{8 1}$ & $\mathbf{1 0 0 . 0}$ \\
\hline Lighting & & \\
Adequate & 63 & 77.8 \\
Deficient & 18 & 22.2 \\
$\quad$ Total & $\mathbf{8 1}$ & $\mathbf{1 0 0 . 0}$ \\
\hline Floor Condition & & 48.1 \\
Permanent & 39 & 51.9 \\
Impermanent & 42 & $\mathbf{1 0 0 . 0}$ \\
Total & $\mathbf{8 1}$ & \\
\hline
\end{tabular}

Table 3. Cross Tabulation of Diarrhea Incidence with Household Sanitation in Kuniran Village, Purwosari SubDistrict, Bojonegoro Regency, East Java, January 2020

\begin{tabular}{lccccc}
\hline \multirow{2}{*}{$\begin{array}{l}\text { Household } \\
\text { Sanitation }\end{array}$} & \multicolumn{4}{c}{ Yes } & \multicolumn{2}{c}{ No } & \multirow{P}{*}{$\boldsymbol{P}$ - Value } \\
\cline { 2 - 5 } & n & \% & n & $\%$ & \\
\hline Good & 3 & 3.7 & 46 & 56.8 \\
\hline Poor & 7 & 8.6 & 25 & 30.9 & 0.040 \\
\hline & $\mathrm{PR}=1.202(95 \% \mathrm{CI} ; 0.987-1.463)$ \\
\hline
\end{tabular}

As many as 7 under-five children (9.9\%) with poor household sanitation experienced diarrhea, while 46 under-five children (56.8\%) did not experience diarrhea with good household sanitation. The correlation resulted in a $p$-value $=0.040$ and a $P R$ value $=1.202$ 
(95\% Cl: $0.987-1.463)$ that showed in Table 3. It means an association between poor household sanitation with diarrhea in under-five children and the probability of diarrhea who remain in poor household sanitation is 1.2 times higher than in good household sanitation.

\section{DISCUSSION}

Diarrhea is a condition where an individual defecated more than three times per day and looser or more liquid (or more frequent passage than normal) (4). Diarrhea is caused by some enterohepatic pathogens that influence the digest system, which is transmitted mainly by the fecal-oral route (12). It can be concluded that household sanitation could be the driving factor of the diarrhea incidence, mostly related to drinking water consumed by the under-five children. Our findings showed that the incidence of diarrhea in under-five children correlated with the household environment's sanitary conditions, including the source of drinking water, availability of healthy latrine, floor condition, and lighting.

A study conducted in South Sumatera Province in 2020 showed that under-five children who consume faucet water have a greater likelihood of experiencing diarrhea than other types of drinking water sources such as refilled water and protected well water $\left(R^{2}=0.712\right)$ (13). Other similar studies strengthened it in Wonokromo in 2019 that under-five children in Kampung Baru Village, Wonokromo Sub-District, Surabaya who consumed drinking water from the river had a higher prevalence of diarrhea than under-five children who consumed well water with $p$-value $=0.087$ (14). A study in Lamper Tengah Semarang in 2015 also mentioned that under-five children who consume packaged drinking water have a higher prevalence and risk of experiencing diarrhea than under-five children who consume bottled drinking water $(p=0.003 ; P R=2.252(95 \% \mathrm{Cl}=1.255-4.042)(15)$.

Poor drinking water quality is at risk of causing disease. Water can be an environmental media for transmitting agents to enter the human body (waterborne disease) and cause infectious disease, both in sanitary water for hygiene purposes such as bathing and washing clothes or drinking water (16-17). In addition, poor self-hygiene behaviour, such as not washing hands before eating and after defecating, can also be a risk factor for diarrhea (18-20).

Our analysis also showed that the availability of a healthy latrine and permanent house's floor was correlated against the incidence of diarrhea in under-five children. Another study conducted in Sukoharjo Regency states that there was a correlation between the quality of latrines (healthy and unhealthy) with diarrhea in children under five $(p=0.025)(21)$. A similar study in Banjarmasin showed that there was a correlation between diarrhea with latrine ownership $(p=0.038)$ and good latrine quality $(p=0.000)(22)$. In addition, a study conducted in Sindu Sub-District, Central Sulawesi, stated that the use of latrines was strongly related to diarrhea $(p=0.003)$ (23). Unavailability of a healthy latrine, which means open defecation might leads vector and rodents into the house and increase the risk of food contamination (24).

Furthermore, the impermanent floor of the house also could be a factor in the incidence of diarrhea in underfive children. A study conducted in Tulang Bawang Barat in 2020 showed that the characteristic of the floor has a relationship with the incidence of diarrhea $(p=0.000)$ (25). A similar study conducted in Banjar Regency also stated that house flooring could be the driving factor of the incidence of diarrhea in under-five children $(p=0,036)$ (26). The House floor should be made from waterproof material, so it is easy to clean. It is indicated that ground or impermanent floor could be the medium of germ and bacteria contacting the children's body through the daily activities carried out (25-26).

However, the lighting factor, including the other physical house parameters like temperature and humidity, does not relate to the incidence of diarrhea in under-five children, according to a study in Muna Barat Regency (27). However, a secondary data-based study in 5 cities in East Java mentions that lighting is also the one component required for a healthy latrine (28). Adequate lighting is considered a single requirement for a sanitary latrine to avoid insects or bacteria contaminating the water.

Contamination of food and beverages with pathogenic bacteria can be closely related to the contamination of drinking water sources and water used for sanitation hygiene purposes by feces, caused by the habit of open defecation, the use of unhealthy latrines, and unsanitary sewerage. This condition allows the occurrence of fecal-oral transmission diseases (21). As a microbiological parameter to maintain the quality of drinking water, the Regulation of Ministry of Health of Republic Indonesia No. 492 year 2010 about Drinking Water Quality Requirements states that the number of E. coli bacteria and total coliforms is 0 per $100 \mathrm{~mL}$ of drinking water samples or in other words, these bacteria are not allowed to be in drinking water (29).

Based on our observations, the source of drinking water for residents who use faucet water can come from the local water company or well water that needs to be processed first, such as being cooked before drinking (30). It can ensure that drinking water 
is free from microorganisms and bacteria like E. coli and other pathogenic bacteria. In addition, it is also necessary to pay attention to how to store drinking water, such as the container used, storage, length of storage time, and make sure that drinking utensils are clean and sterile before it is used (31-32). The behavior of cooking drinking water and the incidence of diarrhea in under-five children is correlated. Mothers who do not boil water for drinking water have a 168 times risk of causing diarrhea in under-five children compared to mothers who cook water first (30).

\section{ACKNOWLEDGEMENTS}

The authors would like to thank the entire Community Field Work Practice (PKL) team in Kuniran Village, Purwosari Sub-District, Bojonegoro Regency 2020 who have contributed to data collection and the village authority also all residents of Kuniran Village, Purwosari Sub-District, Bojonegoro Regency who have become respondents in this study.

\section{CONCLUSION}

This study concludes that there is a relationship between household sanitation, including the source of drinking water, availability of healthy latrine, floor condition, and lighting with the incidence of diarrhea in children under five in Kuniran Village, Purwosari SubDistrict, Bojonegoro Regency. It was also found that under-five children who remain in a house with good household sanitation have a 1.2 times lower risk of suffering diarrhea.

It is recommended in the next research to classify the environmental sanitation variables in more detail based on the existing guidelines, using proper measuring tools and medical record-based data on determining the diarrhea status in under-five children.

\section{REFERENCES}

1. World Health Organization. Water, Sanitation, Hygiene and health A Primer For Health Professionals. Geneva: World Health Organization; 2019. https://www.apps.who.int

2. Sidhi AN, Raharjo M, Astorina N, Dewanti $\mathrm{Y}$. Hubungan Kualitas Sanitasi Lingkungan dan Bakteriologis Air Bersih Terhadap Kejadian Diare Pada Balita di Wilayah Kerja Puskesmas Adiwerna Kabupaten Tegal. Jurnal Kesehatan Masyarakat. 2016;4(3):665-676. http://ejournal-s1.undip.ac.id/ index.php/jkm

3. Minstry of Health of Republic Indonesia. Ministerial Degree of Minstry of Health of Republic Indonesia No 829 Year 1999 about Housing Health Requirements. Jakarta: Minstry of Health of Republic Indonesia.
4. Riddle MS, Dupont HL, Connor BA. ACG Clinical Guideline: Diagnosis, Treatment, and Prevention of Acute Diarrheal Infections in Adults. American Journal of Gastroenterology. 2016;111(5):602-622. http://dx.doi.org/10.1038/ajg.2016.126

5. Hapsari D, Dharmayanti I, Supraptini. Ten-Year Trend of Acute Respiratory Infection (ARI) and Diarrheal Diseases Based on Healthy Houses in Indonesia). Buletin Penelitian Sistem Kesehatan. 2013;16(4):363-372. http://ejournal.litbang. kemkes.go.id/index.php/hsr/article/view/3543

6. Ministry of Health of Republic Indonesia. Information and Data of Toddler in Indonesia. Jakarta: Ministry of Health of Republic Indonesia; 2015. https://www. kemenkes.go.id

7. Ministry of Health of Republic Indonesia. Basic Health Research (Riskesdas). Jakarta: Ministry of Health of Republic Indonesia; 2018. https://www. litbang.kemkes.go.id/laporan-riset-kesehatandasar-riskesdas/

8. Ministry of Health of Republic Indonesia. Health Profile of Indonesia 2018. Jakarta: Ministry of Health of Republic Indonesia; 2019. https://pusdatin. kemkes.go.id/folder/view/01/structure-publikasidata-pusat-data-dan-informasi.html

9. Rimbawati $Y$, Surahman A. Hubungan Sanitasi Lingkungan Dengan Kejadian Diare pada Balita. Jurnal 'Aisyiyah Medika. 2019;4(2):189-198. https://doi.org/10.36729/jam.v4i2.219

10. Hidayat TS, Fuada N. Relationship Between Environmental Sanitation, Morbidity and Nutritional Status Under-Five Children in Indonesia. Jurnal Penelitan Gizi dan Makanan. 2011;34(2):104-113. https://www.ejournal.litbang.kemkes.go.id

11. District Health Office of Bojonegoro. Health Profile of Bojonegoro City in 2019. Bojonegoro: District Health Office of Bojonegoro; 2019.

12. World Health Organization. Safer Water, Better Health. Geneva: World Health Organization; 2019. Geneva: World Health Organization; 2019. 67 p. https://apps.who.int/

13. Ofarimawan D, Ambarita LP. Hubungan Sumber Air Minum dengan Kejadian Diare di Provinsi Sumatera Selatan. Spirakel. 2020;12(1):35-45. http://dx.doi. org/10.22435/spirakel.v12i1.3130

14. Harsa IMS. The Relationship Between Clean Water Sources and the Incidence of Diarrhea in Kampung Baru Resident at Ngagelrejo Wonokromo Surabaya. Journal of Agromedicine and Medical Science. 2019;5(3):124. http://dx.doi.org/10.19184/ ams.v5i3.13813

15. Nurpauji SV. Hubungan Jenis Sumber Air, Kualitas Bakteriologis Air, Personal Hygiene Dengan Kejadian Diare pada Balita di Wilayah Kerja Puskesmas Lamper Tengah Semarang. Journal Kesehatan Masyarakat Universitas Diponegoro. 2015;3(1):18474. http://ejournal-s1.undip.ac.id/ index.php/jkm

16. Levy K. Editorial: Does Poor Water Quality Cause Diarrheal Disease?. American Journal of Tropical Medicine and Hygiene. 2015;93(5):899-900. http:// dx.doi.org/10.4269/aitmh.15-0689 
17. Zulkifli A, Rahmat KB, Ruhban A. Analisis Hubungan Kualitas Air Minum dan Kejadian Diare di Wawondula Sebagai Wilayah Pemberdayaan PT. Vale Sorowako Media Kesehatan Politeknik Kesehatan Makassar. 2019;(23):301-316. http:// dx.doi.org/10.32382/medkes.v12i1.128

18. Tariq M, Farooq S, Khalid S, Shujaat Qureshi I, Khan R, Azhar S, et al. The Annals of Research Association of Literacy and Knowledge Regarding Personal Hygiene among Mothers of Children Suffering from Acute Diarrhea. The Annals of Research. 2020;1(1):1-6. https://annalsor.com/ association-of-literacy-and-knowledge-regardingpersonal-hygiene-among-mothers-of-childrensuffering-from-acute-diarrhea/

19. Sidabalok DL, Samsudin S, Djaja IM. Relationship between Environmental Factors and Personal Hygiene with Diarrhea among Children Under Five in West Kotawaringin, Central Kalimantan. The $6^{\text {th }}$ International Conference on Public Health. 2019;1(1):31-39. https://doi.org/10.26911/ the6thicph-FP.01.05

20. Andualem Z, Dagne H, Taddese AA, Dagnew B. Mothers' Handwashing Knowledge as a Predictor of Diarrheal Disease Among Under-Five Children Visiting Pediatric Ward in University of Gondar Comprehensive Specialized Hospital, Northwest Ethiopia. Pediatric Health Medicine Therapeutic. 2019;(10)1:189-194. http://dx.doi.org/10.2147/ phmt.s233337

21. Hina YFR, Simanjuntak S, Simbolon I. Perilaku Mencuci Tangan Mahasiswa Berasrama dan Derajat Kebersihan Tangan: Indikasi Program Pencegahan Infeksi Fekal-Oral. Journal Skolastik Keperawatan. 2016;2(2):151-158. http://dx.doi.org/10.35974/jsk. v2i2.557

22. Kasman K, Ishak NI. Kepemilikan Jamban Terhadap Kejadian Diare pada Balita di Kota Banjarmasin. Jurnal Publikasi Kesehatan Masyarakat Indonesia. 2020;7(1):28-33. http://dx.doi.org/10.20527/jpkmi. v7i1.8790

23. Ifandi S. The Relationship of Toilet Utilization and Water Resources Utilization to the Occurrence of Diarrhea in Infants in Sindue District of Donggala Regency, Central. 2017;2(2):38-44. https://afiasi. unwir.ac.id/index.php/afiasi/article/view/45

24. Nurlila RU. Faktor Risiko Kejadian Diare di Wilayah Kerja Puskesmas Langara Kecamatan
Wawonii Barat Sulawesi Tenggara. Prosiding Seminar Nasional. 2020;2(1):1-7. http://semnas. poltekkesdepkes-sby.ac.id

25. Sriyani A, Berawi N, Bakri S, Kaskoyo $H$. Development of Prediction Model for Childhood Diarrhea Based on Maternal Care Variables, Characteristics of Children, Demography and Sanitation in Study Environment Tulang Bawang Barat Regency. International Journal of Progressive Sciences and Technologies. 2020;23(2):354-365. https://ijpsat.es/index.php/ijpsat/article/view/2366

26. Rokhman O. Hubungan Antara Sanitasi Total dengan Kejadian Diare pada Balita di Wilayah Kerja Puskesmas Banjar III Kota Banjar Tahun 2017. Jurnal Kesehatan Mandiri Aktif. 2018;1(2):90-96. http://jurnal.stikesbp.ac.id/index.php/jkma/article/ view/61

27. Armin, Sabilu Y, Sabril Munandar. Hubungan Sanitasi Ligkungan dengan Kejadian Penyakit Diare Balita di Desa Tanjung Pinang Kecamatan Kusambi Kabupaten Muna Barat tahun 2017. Jurnal IImiah Mahasiswa Kesehatan Masyarakat. 2017;2(7):1-10. http://ojs.uho.ac.id/index.php/ JIMKESMAS/article/view/3422

28. Prakoso ID. Correlation Between Access of Drinking Water and Sanitation with Diarrhea Incidence in East Java. Jurnal Berkala Epidemiologi. 2020;8(1):4229. http://dx.doi.org/10.20473/jbe.v8i12020.42-49

29. Ministry of Health of Republic Indonesia. Regulation of Ministry of Health of Republic Indonesia No. 492 year 2010 about Drinking Water Quality Requirements. Jakarta: Ministry of Health of Republic Indonesia; 2010.

30. Hairani B, Andiarsa D. Correlation Among Mother's Knowledge and Practice of Boiling Drinking Water to The Incidences of Toddler Diarrhea in Puskesmas Baringin Tapin District 2014. 2017;3(1):7-11. Journal of Helath Epidemiology and Communicable Disease. $\quad$ https://r2kn.litbang.kemkes.go.id/ handle/123456789/82585

31. Hendrastuti CB. Hubungan Tindakan Pencegahan Ibu dengan Kejadian Diare pada Balita. Jurnal PROMKES. 2019;7(2):215-222. http://dx.doi. org/10.20473/jpk.v7.i2.2019.215-222

32. Meliyanti F. Faktor-Faktor yang Berhubungan dengan Kejadian Diare Pada Balita. Jurnal Aisyah: Jurnal IImu Kesehatan. 2016;1(2):09-16. http:// dx.doi.org/10.30604/jika.v1i2.15 